Canadian University Music Review

Canadian University Music Review

Revue de musique des universités canadiennes

\title{
Music about Music: the First String Quartet, Opus 37, in C, by \\ Karol Szymanowski
}

\section{Paul Cadrin}

Numéro 7, 1986

URI : https://id.erudit.org/iderudit/1014092ar

DOI : https://doi.org/10.7202/1014092ar

Aller au sommaire du numéro

\section{Éditeur(s)}

Canadian University Music Society / Société de musique des universités canadiennes

\section{ISSN}

0710-0353 (imprimé)

2291-2436 (numérique)

Découvrir la revue

\section{Citer cet article}

Cadrin, P. (1986). Music about Music: the First String Quartet, Opus 37, in C, by Karol Szymanowski. Canadian University Music Review / Revue de musique des universités canadiennes, (7), 171-187. https://doi.org/10.7202/1014092ar

All Rights Reserved ( C Canadian University Music Society / Société de musique des universités canadiennes, 1986
Ce document est protégé par la loi sur le droit d'auteur. L'utilisation des services d'Érudit (y compris la reproduction) est assujettie à sa politique d'utilisation que vous pouvez consulter en ligne.

https://apropos.erudit.org/fr/usagers/politique-dutilisation/ 


\title{
MUSIC ABOUT MUSIC: THE FIRST STRING QUARTET, OPUS 37, IN C, BY KAROL SZYMANOWSKI
}

\author{
Paul Cadrin
}

In their recent book about Stravinsky, the Dutch composer Louis Andriessen and critic Elmer Schonberger propose the following allegory for music:

We have to imagine an art of painting that has its roots in one single painting... That one painting portrays the last tree and the last landscape. After the completion of that painting, the tree was cut down and the landscape devastated. Since then, there were no more trees or landscapes to be seen. But that painting inspired other painters to paint trees and landscapes. The resulting paintings, in their turn, inspired a new generation of painters. In that way, it is possible that the present practitioners of this school paint trees and landscapes which, it must be said, in no way resemble the last tree and the last landscape. This school of painting is similar to what happens in music. Just as treeand-landscape paintings portray other tree-and-landscape paintings, music portrays other music.

[Andriessen and Schonberger 1983: 30]

If this view of music is exact, in what way, one may ask, is Szymanowski's First String Quartet different from any other piece of music? In what particular way can it be said to be "music about music"? Careful analysis suggests that, within the Quartet, the evolution of the composer's style, from his upbringing in the hotbed of German late romanticism to his discovery of the French-Russian avant-garde in 1913 , is retraced. 
The First String Quartet, Opus 37, in C was composed in 1917, at the peak of the composer's most creative period. Before the work was completed, however, the Szymanowski family estate, in Ukraine, was razed to the ground in the October Revolution. The two compositions on which Szymanowski was working at the time, the Quartet and the cantata Agave, were never to be completed as planned. Of the projected four movements of the Quartet, three were later revised for publication. The original plan was to include a sonata-allegro, a scherzo, a theme and variations for the slow movement, and a fugue for the finale. According to Michałowski [1967: 137], the scherzo was reworked to become the last movement, presumably by integrating elements of fugal writing within the structure and character of a scherzo. On the other hand, the first movement is preceded with a rather elaborate slow introduction, a most unusual feature in the quartet literature of the time, possibly as a means of compensating for the missing fourth movement.

Certain aspects of the Quartet stand out as strangely anachronistic with respect to other works of the same creative period, for example, the Third Symphony, Opus 27 (1914-16), the First Violin Concerto, Opus 35 (1916), or the Third Piano Sonata, Opus 36 (1917). No indication of tonality had appeared in the title of a composition since the Second Piano Sonata, in A major (1911). The Quartet was to be the last work to carry such an indication. This suggests the composer's awareness that this work belongs to a different stylistic lineage. As noted by Alistair Wightman:

The progressive disruption of tonality, a process well under way in the earlier war-time works, seems to have been arrested in the first of the Quartets.

[Wightman 1972: 94]

To a certain extent, this anachronism could be credited to the composer's discomfort with the resources of the string quartet. At the age of 34 , this was his first venture into the medium. The only comparable work written previously, the Piano Trio, opus 16 , had been withdrawn 
after its first performance, in 1909. In a letter to Szymanowski dated 24 July 1917, the violinist Pawel Kochański had this to say in reaction to the composer's announcement that he was writing a quartet (the composer's letter is lost):

It is strange how one changes. Do you remember, you used to dislike the quartet, to say it could not give you full satisfaction, not enough sound?

[Chylińska 1982: 506] ${ }^{1}$

In addition to his discomfort with the quartet as an ensemble, Szymanowski apparently had to cope with a disinclination to write works of "pure" music, that is, music which is not based on a text or inspired by a programme. Even the Second Symphony and the First Violin Concerto are known to have programmatic backgrounds, 2 not to mention the fact that more than half of his total output consists of songs, a substantial corpus little known outside Poland. As far as we know, however, the Quartet is "pure" music.

Lacking an extra-musical programme to guide his inspiration, Szymanowski reckons with his own evolution as a composer, from his youthful fervour for the German romanticism of Wagner, Strauss, and Reger, through his discovery of French impressionism, particularly of the music of Ravel, to his recent infatuation with the aesthetics of the French-Russian avant-garde. The manifestation of each of these influences will now be traced in the Quartet.

1 “...dziwne to, ze siẹ tak zmienia, pamiẹtasz jak nie lubiteś kwartety, mowiłes, ze to nie zadawalnia Ciebie, ze za mato brzmienia?" The author is grateful to Mr. Leszek M. Karpinski, of the University of British Columbia, for his help with the translation of this excerpt from the correspondence.

2 On the Second Symphony, see Rubinstein (1973: 376); on the First Concerto, see Samson (1980:114-120). 
The dominant influence on Szymanowski's musical education, from his early training at home and in Elisavetgrad under Gustav Neuhaus to his studies with Zawirski and Noskowski in Warsaw, was that of German late romanticism. His Second Symphony, opus 19, in Bb major (1910) and his Second Piano Sonata, opus 21, in A major (1911) mark the culmination of this influence. The structure, harmonic vocabulary, and contrapuntal processes of these two works invite a comparison with Reger, while the orchestration of the Symphony is clearly derived from Wagner and Strauss.

The influence of Wagner on the Quartet is very diffuse. In one instance, however, it comes close to the surface. In the exposition of the first movement, the link between the transition and the beginning of the second subject group (mm. 42-44) is based on the Tristan chord and its resolution (see example 1). The complex contrapuntal ornamentation does not entirely obscure the underlying progression. The relationship with the Prelude is further confirmed by the fact that the dominant harmony on $\mathrm{E}$ of $\mathrm{m} . \mathbf{4 5}$ moves up a semitone to an F-Major triad at m. 47 , followed at m. 49 by motion to a D-major chord in first inversion, as in mm. 16-18 of the Prelude.

With the exception of local events of the kind just described, the influence of Wagner on the Quartet is not readily discernible. It is distilled through that of later German composers, particularly Reger. The five string quartets published by this composer (Opus 54, no 1 and 2; opus 74; opus 109; opus 121) are among his most durable achievements. Szymanowski is likely to have known these works, and their influence is felt in many aspects of his own quartet.

The plan initially chosen by Szymanowski is a case in point. The theme and variations for the slow movement is a staple of the music of Reger. It is found in four of the five quartets. In the first and fourth, it is coupled with a fugue in the last movement, as in Szymanowski's plan. Furthermore, the theme of the third movement of the Fourth Quartet, opus 109, is titled "Canzona", while Szymanowski's theme is marked 
"in modo d'una canzone". In all cases, the final fugues are spirited virtuoso movements based on unequivocally tonal subjects, in strong contrast with the intricate chromatic lacework of the foregoing variations.

Curiously, in modifying his plan to accommodate a three movement scheme, Szymanowski may again have been following a precedent set by Reger. The latter's Second Quartet, opus 54, number 2, is in three movements, the second and third of which are respectively a theme and variations and a fugue. This was also the plan chosen by Szymanowski for the two major works of his German period, the Second Symphony and the Second Piano Sonata.

These similarities of structure are corroborated by similarities of tonalharmonic language. These include a harmonic vocabulary dominated by four-note chords of the dominant-seventh, diminished seventh, half-diminished seventh, German and French sixth types. Furthermore, these four-note chords occur in a tonal syntax which is subject to enharmonic reinterpretation as well as to so-called irregular resolutions, creating a constant tonal flux in which each progression is locally justifiable (see example 2). In contrast with the prevailing tonalharmonic system just described, there are short segments in which the juxtaposition of consonant triads belonging to different diatonic collections produces an effect which I would call "consonant chromaticism" (see example 3). Instances of this tonal-harmonic idiom are found in Wagner, for example, in Kurwenal's satirical song, in Act I Scene 2 of Tristan (see example 4).

In spite of the frequency of harmonies belonging to the dominant family, perfect authentic cadences are rare and reserved for major punctuations. In the Szymanowski Quartet, the only perfect authentic cadence found in the course of a movement closes the theme, the Canzona, of the second movement (m. 10). Finally, the use of tonally 
unequivocal, almost Handelian, fugue subjects for the last movement is a feature of the tonal-harmonic language which has already been noted (see example 5).

With the exception of the last, all the traits mentioned in the preceding paragraphs are found in the first two movements of the Szymanowski Quartet. In fact, they are not found beyond the second variation of the middle movement. The presence of the fugue subject in this list may be credited to the reorganization of materials subsequent to the adoption of the three-movement scheme. It is therefore plausible that Szymanowski drew his inspiration for the overall scheme of the Quartet, as well as for the tonal-harmonic language of the first half, from Reger.

A set of variations lends itself particularly well to the unfolding of stylistic transformations. The second movement of the First Quartet is a good case in point. If the theme and first variation are reminiscent of the music of Reger, the second and third variations are more intimately related to the style which Szymanowski evolved after 1913, particularly in his works for violin and piano, the Notturno $e$ Tarentella, opus 28, and the three Mythes, opus 30.

These works display stylistic features which are more easily related to the works of the French impressionists than to those of the German school. In contrast with the relentless tonal flux which characterizes the music of Reger, this music juxtaposes static planes of tonally enigmatic materials. For example, tonal fluctuation around a pedal combined with vacillations of the metric framework are found in the beginning of the second variation of the Quartet as well as at the beginning of the third movement of the Ravel Quartet (see example 6). ${ }^{3}$ The unusual texture of the third variation, with its tremolando accompaniment in

3 In order to understand the metric fluctuation at the beginning of the second variation, one must note that the change of metre from $3 / 4$ to $6 / 8$, at $\mathrm{m}$. 28 , becomes perceptible only with the upbeat to m. 31 . 
the lower register supporting static melodic motives, is also reminiscent of Ravel, particularly of his works for piano like Jeux d'eau (see example 7).

The prevailing harmonic sonorities of the third variation belong to the whole-tone family. The third movement, on the other hand, prominently features chords of the ninth, eleventh, and thirteenth. This marks a significant departure from the harmonic vocabulary of the first movement described above, a mutation which may be credited in good part to Szymanowski's discovery of French impressionism.

Beyond a fugal exposition at the beginning of two of its principal sections (mm. 8-19 and 78-97), the third movement is not a fugue. The prevalent texture is homophonic, rather than polyphonic, and the emphasis is on the repetition of motives over tense harmonic conglomerates, rather than on imitative writing. Again, we are reminded that this movement was meant to amalgamate fugal procedures with the structure and character of a scherzo. Superficially, the most striking feature of this movement is the presence of four different, concurrent key signatures. In that respect, it is unique in the works of Szymanowski and, to this writer's knowledge, the only example of its kind in the string quartet repertoire. While this movement is most explicit and systematic in its use of superimposed tonalities, other works of the period 1914-1917 had already made passing use of this technique, for example, "Tantis le bouffon", the second of the three Masques, opus 34, for piano (see example 8).

Although one may find glimmers of bitonality in the music of Richard Strauss, particularly in Salome, it came to be identified, after 1911, with the French-Russian avant-garde. ${ }^{4}$ Even before Darius Milhaud made himself the champion of polytonality, Ravel, Koechlin, Casella, de Falla, Roussel, and, of course, Stravinsky were associated with this

4 See Koechlin (1925: 696-738). 
trend in the years immediately preceding World War I.5 In his deliberate attempt at breaking the shackles of German romanticism, Szymanowski was likely to be attracted by a musical current which was most explicit in its reaction against the influence of Wagner. The idiom of that avant-garde was polytonality.

Szymanowski's admiration for Stravinsky, first expressed in a letter to Stefan Spiess dated 14 October 1913, was later to materialize in an article published in 1924.6 Nevertheless, one would have a hard time finding specific aspects of his new style which would be creditable to the influence of Stravinsky in particular. In the words of Alistair Wightman:

Stravinsky's influence was not so much direct as catalytic. Szymanowski's own form of impressionism, for want of a better word, has none of the primitivism of either Petrouchka or Le Sacre du printemps.

[Wightman 1982: xvii]

In adopting a strictly polytonal scheme for his third movement, therefore, Szymanowski was experimenting with a technique whose bases he was likely to have discovered during his trip to Paris before the War, but which he stringently carried to extremes for which he had no prototype of comparable extent or complexity.

A further indication of the catalytic influence of Stravinsky may be found in the contrasting section, corresponding to the trio in a regular scherzo. This short section (mm. 138-188) is based on a rousing melody propelled by a lilting accompaniment evocative of folk dance music (see example 9). While this author has been unable to find in Polish folk

5 While these composers are of various ethnic origins, they were all active in Paris at the time.

6 “Igor Stravinsky," Warszawianka, 1924, no 7 (Maciejewski 1967: 130). 
music a plausible source for this theme, there is no doubt that a stylized dance tune of this kind marks a turning point in the evolution of the composer. It is a foretaste of the use of explicitely Polish folk material found in the works written after 1920.

It would be most unfortunate if the emphasis laid on influences in this paper would leave the reader with the impression that Szymanowski was a composer of meagre creative aptitudes. While many creators of great music have thought it was important to learn from other composers, Szymanowski felt this was a particularly urgent responsibility for Polish composers. This is expressed in a remarkable way in an article published in 1920,7 which may be read as his aesthetic credo:

Let our music be national in its Polish characteristics but not falter in striving to attain universality, let it be national but not provincial...Let all the new ideas and thoughts which are born into the world today come to us and enrich our minds, for this is a luxury that we have dispensed of for so many decades.

[Maciejewski and Aprahamian 1970: 91]

Fifty years after his death on 29 March 1937, the significance of Szymanowski, both in his own time and today, is just coming to light. Here is a composer who could let his music portray other musics insofar as this would not imperil the unique qualities of his style. The First String Quartet, opus 37, sometimes considered to be of marginal significance, appears to hold a key to an understanding of this style.

7 Quoted from "Thoughts on Polish criticism in music today," in The Warsaw New Literary Review July 1920, translated and edited by B.M. Maciejewski. 


\section{REFERENCES}

ANDRIESSEN, L. \& E. SCHÖNBERGER

1983: "Ars imitatio artis", Key Notes 18/2: 30-31; English translation of an excerpt from Het apollinisch uurwek (Amsterdam: Bezige Bij, 1983).

CHYLIŃSKA, T., ed.

1982: Karol Szymanowski: Korrespondencja, volume 1 (1903-1919). Krakow:

PWM Edition.

KOECHLIN, C.

1925: "Evolution de l'harmonie: Période contemporaine depuis Bizet et César Franck jusqu'à nos jours," in Encyclopédie de la musique et dictionnaire du Conservatoire, 2 deuxième partie, volume 1, pp. 591-760. Edited by Albert Lavignac and Lionel de la Laurencie. Paris: Delagrave.

MACIEJEWSKI, B.M.

1967: Karol Szymanowski: His Life and Music. Foreward by Felix Aprahamian. London: Poets' and Painters' Press.

MACIEJEWSKI, B.M. and F. APRAHAMIAN

1970: Karol Szymanowski and Jan Smeterlin: Correspondence and Essays. Translated, edited, and annotated by B.M. Maciejewski and F. Aprahamian. London: Allegro Press.

MICHALOWSKI, $\mathrm{K}$.

1967: Karol Szymanowski 1882-1937: Katalog tematyczny dziel $i$ bibliografia [Thematic Catalogue of Works and Bibiliography]. Kraków: PWM Edition.

RUBINSTEIN, A.

1973: My Young Years. New York: Alfred A. Knopf.

SAMSON, J.

1980: The Music of Szymanowski. London: Kahn \& Averill.

WIGHTMAN, A.

1972: "The Music of Karol Szymanowski." Unpublished Ph.D. dissertation. University of York.

1982: Preface to vol. 8 (Piano Works) of Karol Szymanowski: Complete Edition. Teresa Chylińska general editor. Kraków: PWM. 


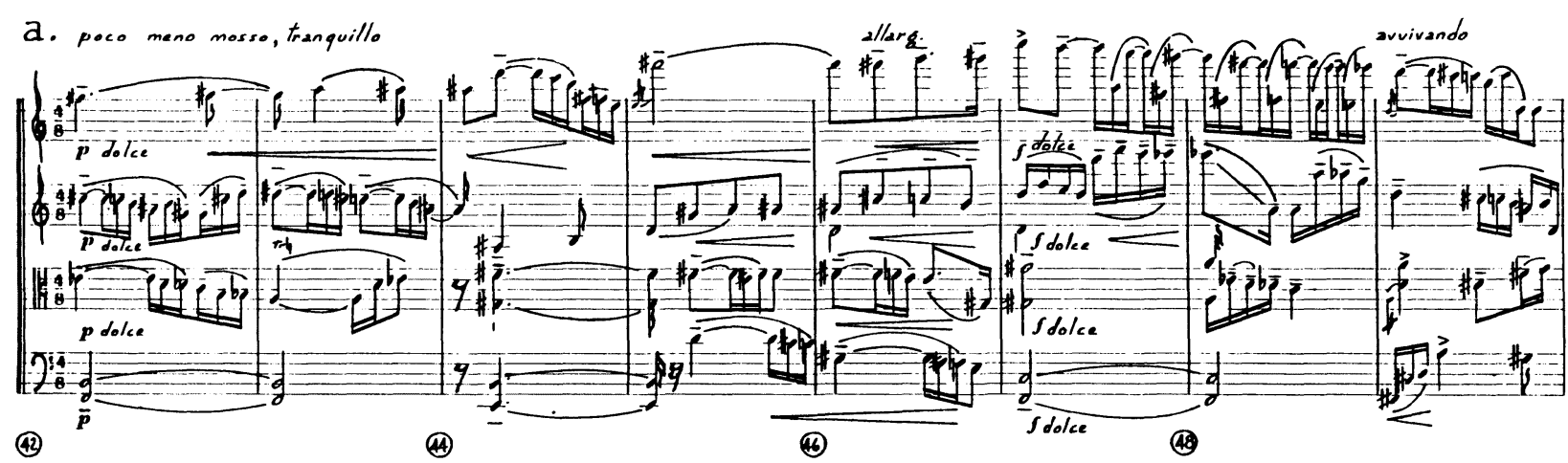

(42)

(4)

(16)

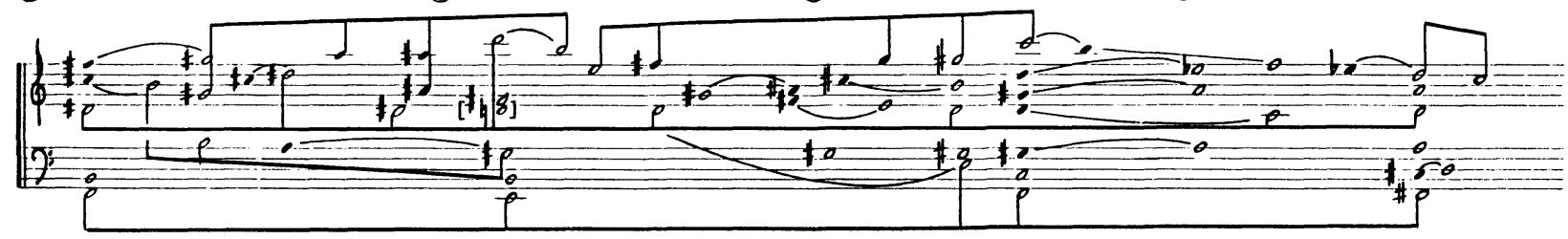

(c) Copyripht 1925 by Universal sition A.G., Wien

All $\mathrm{r}$ ights reserved

Used by permission of European American Music Distributor
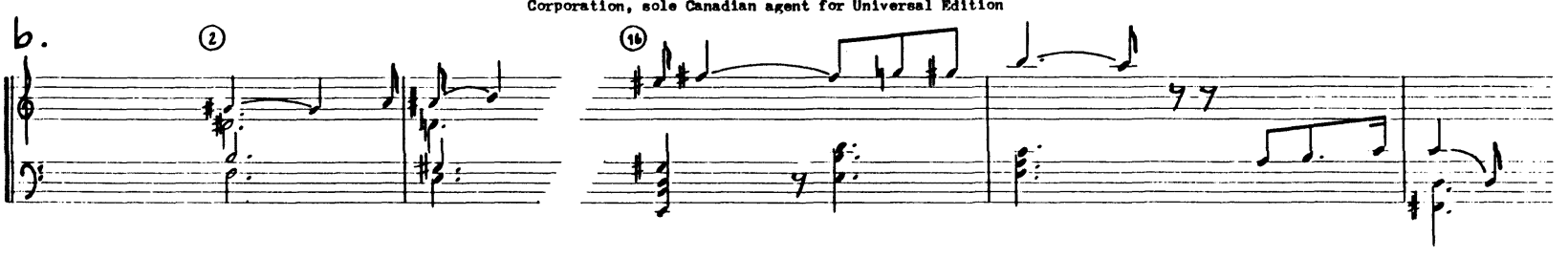

Example 1

Comparison of a) mm. $42-49$ of the first movement of the Quartet with b) $\mathrm{mm}$. 2-3 and 16-18 of the Prelude to Tristan und Isolde by Wagner. 

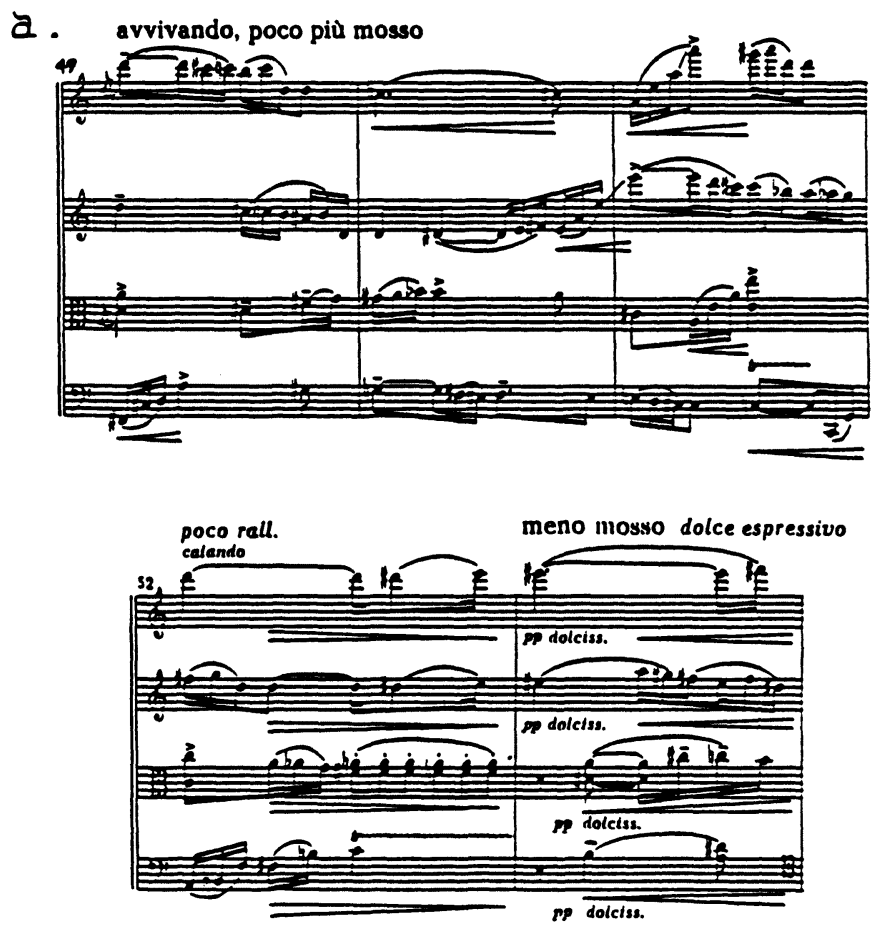

(C) Cooyriont 1925 by Universal Edition A.G., wien Copyright renewed

Used by permission of European American Music Jistribucors

Corporation, sole Canadian agent for Universal Edition

b.

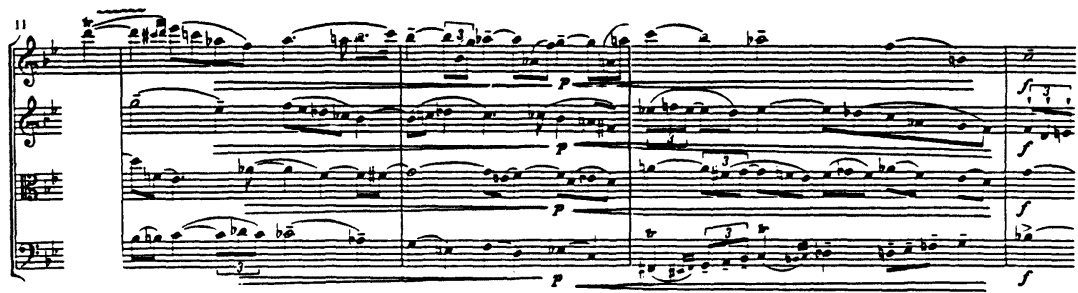

Comparison of a) mm. 49-53 of the first movement of the Quartet with b) mm. 12-14 of the first movement of the First Quartet, opus 54, no.1, by Reger. 
a.

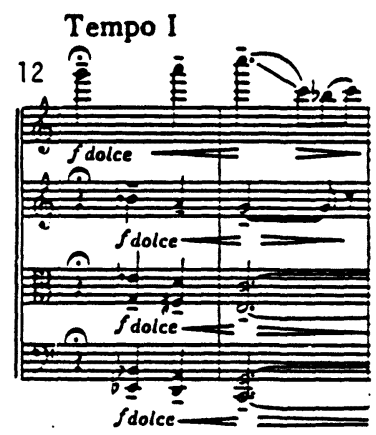

(i) Coovrignt 1925 by universal Edition A.G., Wien copyright renewed

All rignts reserved

Used by permission of European American Music Distributors

Corporation, sole Canadian agent for Universal Edition

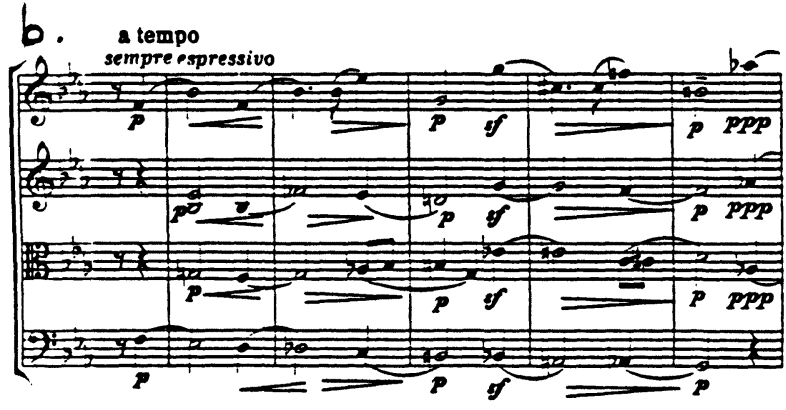

Example ?

Comparison of a) mm. 12-13 of the first movement of the Quartet with b) mm. 96-101 of the first movement of the Fourth Quartet, opus 109, in Eb major, by Reger.

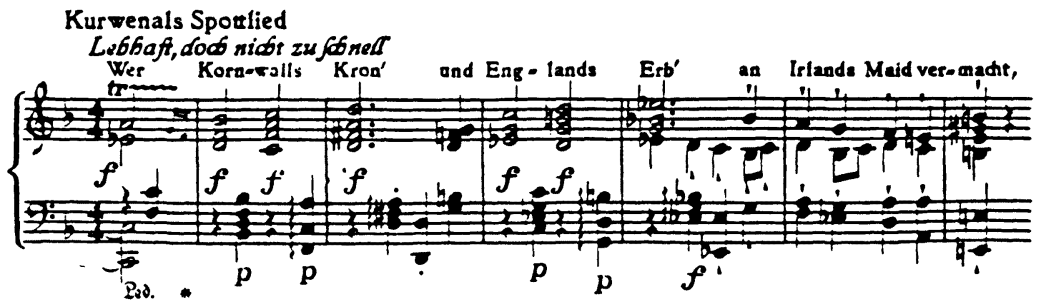

Tristan und Isolde, Act I, sc. 2. 


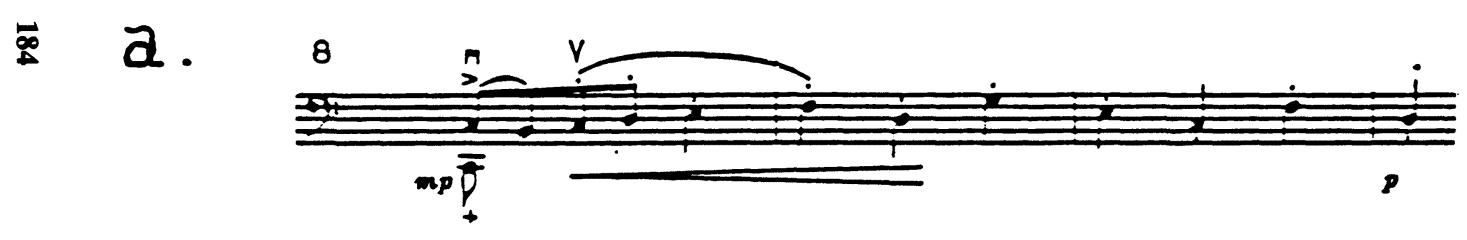

(c) Copyright 1925 by Universal Edition A.G., Wien Copyright renewed

All rights reserved

Used by permission of European American Music Distributors

Corporation, sole Canadian agent for Universal Edition
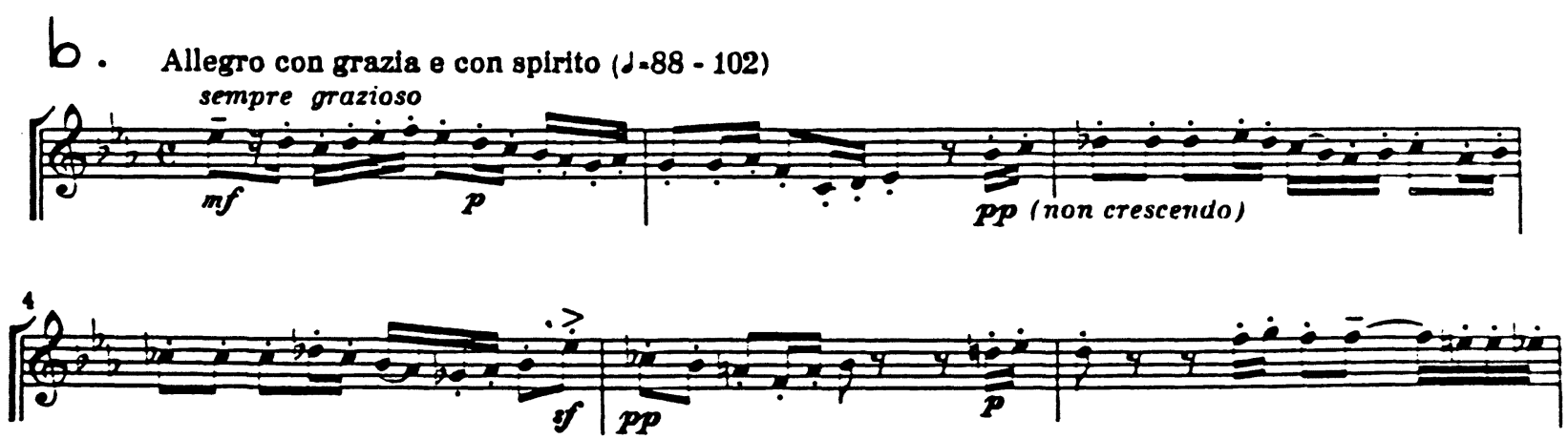

Example 5

Comparison of a) mm. 8-10 of the third movement of the Quartet with b) mm. 1-6 of the fourth movement of the Fourth Quartet, opus 109, in Eb major, by Reger. 
a.
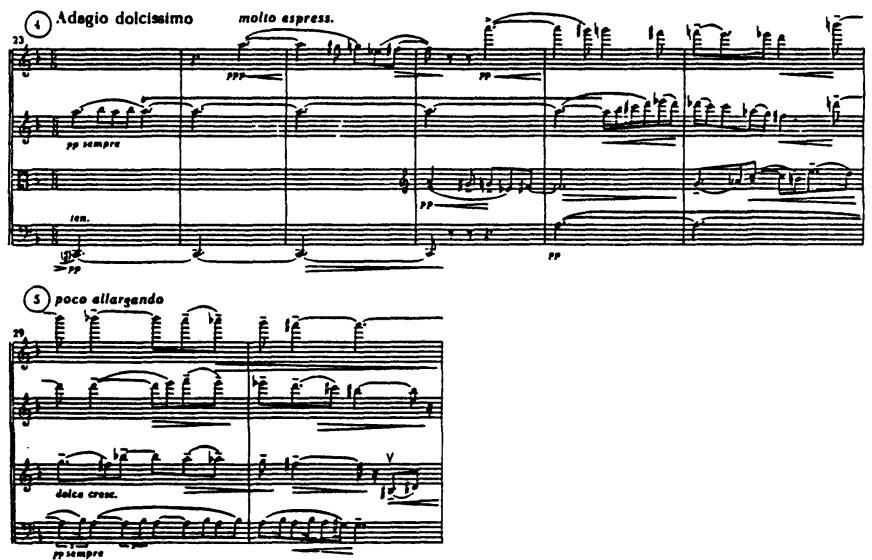

(c) Copyriant 1925 by Universal Edition A.S., Wien Copyright renewed All rights reserved

Used by permission of European American Music Distributors Corporation, sole Canadian agent for Universal Edition

b.

III

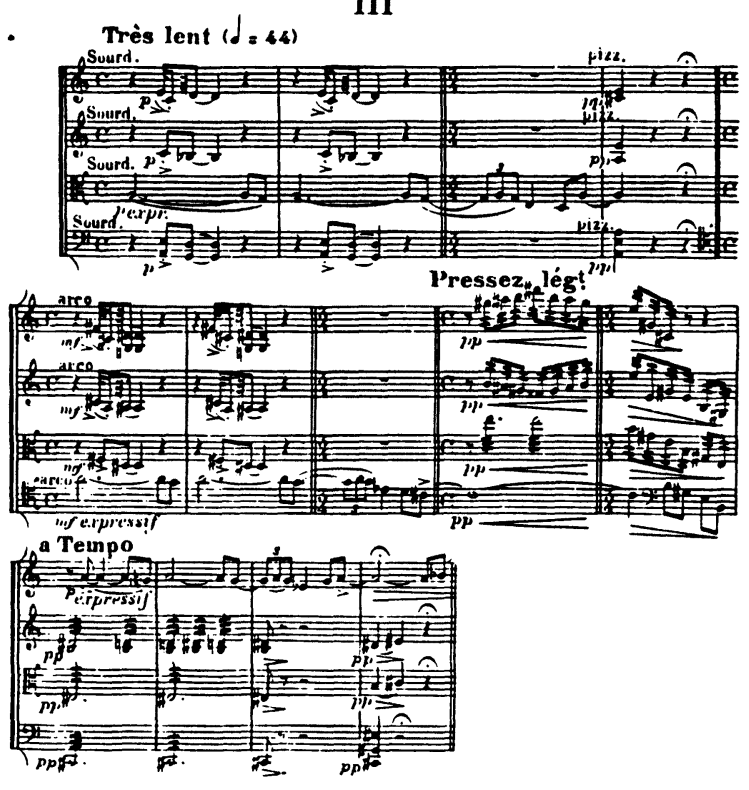

Comparison of a) mm. 23-30 of the second movement of the Quartet with b) mm. 1-13 of the third movement of the Quartet in F major by Ravel. 

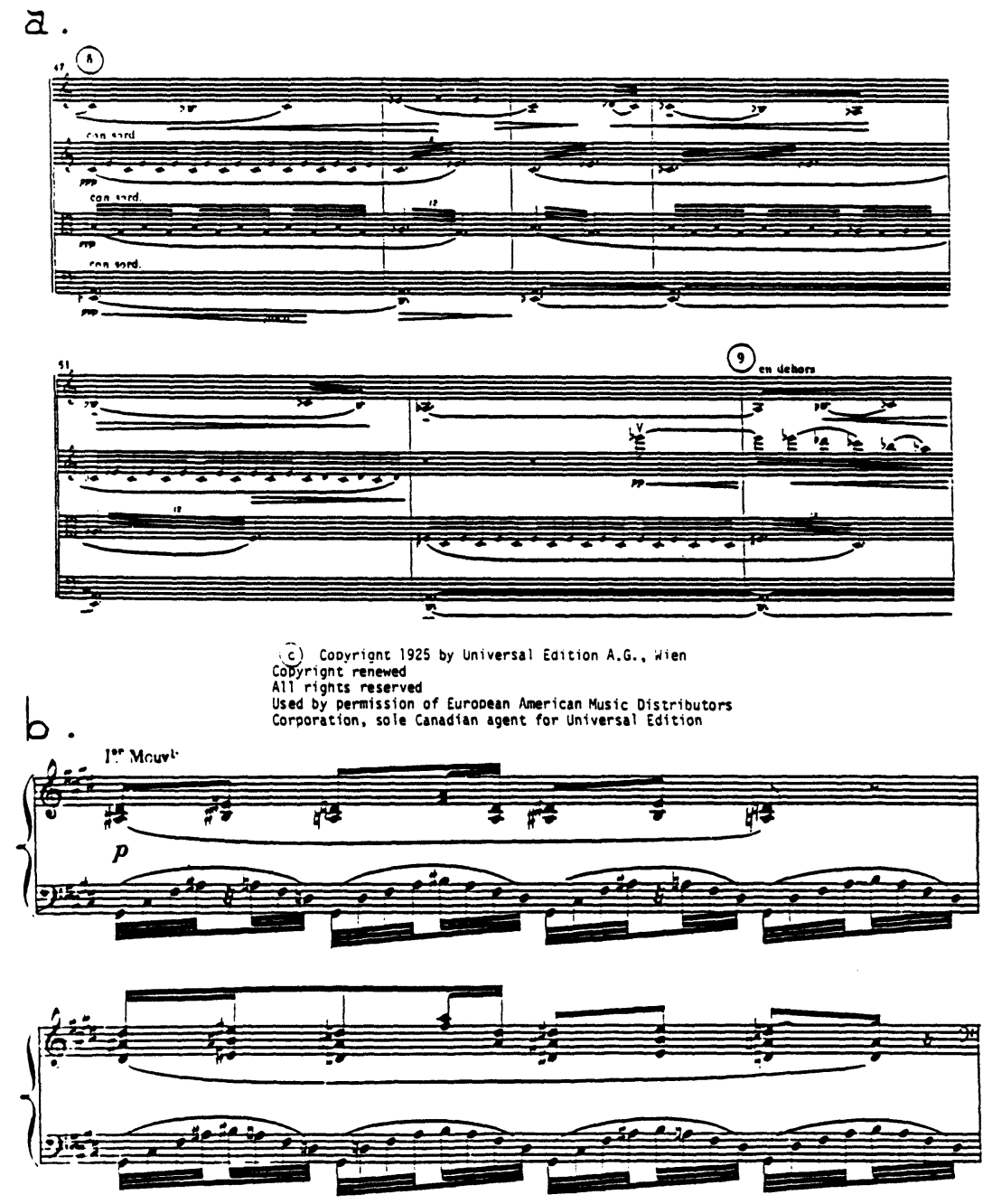

Comparison of a) mm. 47-52 of the second movement of the Quartet with b) mm. 51-52 of Jeux d'eau by Ravel. 

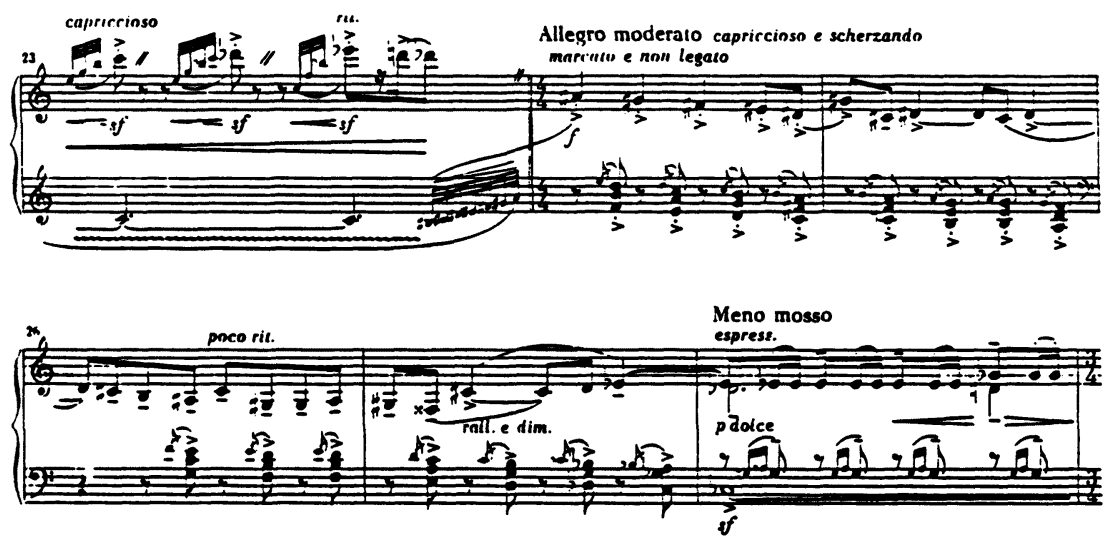

(c) Copyright 1919 by Uaiversal Bdition A.G., wien Copyrighe renawed 1947

Copyrithe of the revised version 1982

by Univereal Edition A.G., Wien

Used by periseston of European Anerican Mulic Distributors

Corporation, sole Cansdian apent for Universal Edstion

Examble 8

Mm. 23-28 of "Tantris le bouffon"

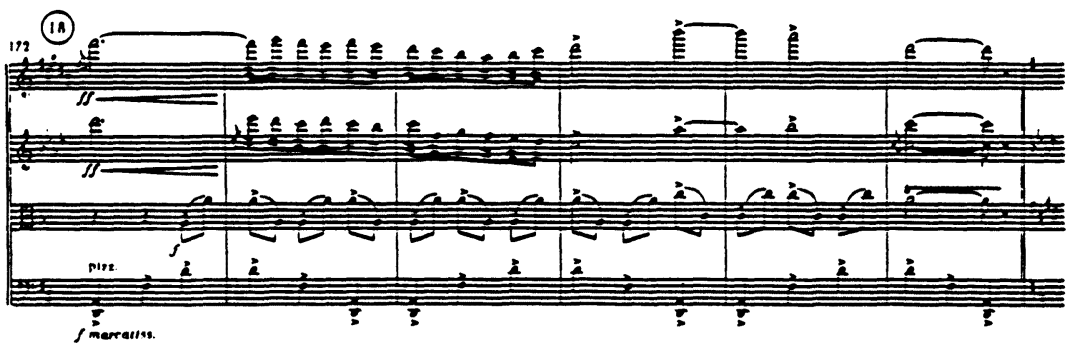

(i) Cooyrignt 1925 by Universai Eaition A.G.. Wien CoDyrignt renewed

All rignts reserved

Used by permission of Eurodean American Music Distributors

Corporation, sole Canadian agent for Universal Edition

Mm. 172-177 of the third movement of the Quartet. 